\title{
Vətəndaş Elmində İstifadə Olunan Açıq Kodlu Proqram Vasitələrinin Təhlili
}

\author{
Təhmasib Fətəliyev, Nərgiz Verdiyeva \\ AMEA İnformasiya Texnologiyaları İnstitutu, Bakı, Azərbaycan \\ depart3@iit.ab.az
}

\begin{abstract}
Xülasə- Məqalə vətəndaş elminin formalaşması və inkişafında informasiya texnologiyalarının vo açıq kodlu proqram məhsullarının tətbiqi və təhlili məsələlərinə həsr olunmuşdur. Vətəndaş elminin inkişafının spesifik xüsusiyyətləri və müasir texnologiyaların ona təsir mexanizmləri təhlil olunmuşdur. Müvafiq layihələrin həyata keçirilməsində açıq proqram vasitələrindən istifadə imkanları göstərilmişdir.
\end{abstract}

Açar sözlor-e-elm, votondaş elmi, proqram vasitolori, sosial media, votondaş elmi layiholori

\section{GIiRIS}

IKKT-nin cəmiyyətin müxtəlif sahələrinə sürətlə tətbiqi insanlar arasında münasibətlərin xarakterinə, biznes prinsiplərinə və dövlət idarəçiliyinəyeniliklər gətirir. Virtual cəmiyyətlər formalaşır, yeni informasiya münasibətləri yaradılır, müəyyən informasiya maraqları üzrə istifadəçilərin qruplaşması baş verir. İnformasiya Comiyyəti quruculuğuna xas olan bu proseslər elmi fəaliyyətdə də müşahidə olunur və nəticədə elmi-tədqiqatların xarakteri dəyişir, yeni formaları meydana gəlir.

Qlobal problemlərin həllində sosial qüvvə kimi elmin əhəmiyyətli rolu vardır.Müasir elmə xas olan beynəlxalq əməkdaşlıq və qloballaşma, qlobal problemlərin həllində müxtəlif elm sahələrinin inteqrasiyası və dünyanın müxtəlif ölkələrinin aparıcı mütəxəssislərinin birgə elmi fəaliyyətə cəlb olunmasiyeni texnologiyaların verdiyi imkanlar sahəsində daha da inkişaf etdirilir. $\mathrm{Bu}$ imkanlar həmçinine-elmin yeni istiqaməti kimi formalaşanvə vətəndaşların elmi-tədqiqatlarda iştirakı ilə xarakterizə olunanvətəndaş elminin inkişafina da böyüktəkan vermişdir.

Təqdim edilən iş̧ə aktual bir məsələ kimivətəndaş elmininformalaşması və inkişafında müasir texnologiyaların rolu və istifadə olunan açıq proqram vasitələrinin spesifik xüsusiyyətləri təhlil olunmuşdur.

\section{VӘTӘNDAŞ ELMININ FORMALAŞMASINDA MÜASIR İNFORMASIYA TEXNOLOGIYALARININ ROLU}

Son onilliklər ərzində informatika elminin, xüsusilə böyük həcmli verilənlərin emalı prosesinin inkişafi, veb texnologiyalarına əsaslanan qrafiki istifadəçi interfeysləri və coğrafi informasiya sistemləri, mobil texnologiyalar, smartfon, planşet kompüterlər və digər portativ cihazlar vətəndaş elminin yaranmasında mühüm rol oynamışdır. Vatวndaş elmi əksəriyyətinin ixtisas üzrə ilkin hazırlığı olmayan çoxlu sayda həvəskarın elmi-tədqiqatların aparılmasına könüllü cəlb olunması konsepsiyasıdır. Bu konsepsiyanın reallaşdırılmasını həyata keçirən həmin həvəskar iştirakçllar vətəndaş alim adlandırılır [1].

Sosial şəbəkə, blog və wiki saytlar kimi sosial əməkdaşlıq texnologiyaları oxşar təcrübə və maraqları olan insanlar arasında qarşılıqlı münasibətləri asanlaşdıran Facebook, Twitter, LinkedIn, MySpace va Vikipediya kimi çoxsaylı online icmaların yaranmasına səbəb olmuşdur. Yeni texnologiyalar alimlərin "kollektiv bilik" əldə etmək arzusunu reallaşdırır. Wiki texnologiyası bu sahədə mühüm əhəmiyyət kəsb edir. Onun tətbiqi İnternetdə xüsusi yer alan Wikimedia hərəkatını yaratmışdır. Bu hərəkat tədris materialları şəklində biliklərin sərbəst yaradılması və dəstəyi üçün ümumi məqsəd və fəaliyyətlərini bölüşən insanlar və onların qruplarından ibarətdir. Qeyd etmək lazımdır ki, Wikimediya layihələrində müəlliflər kollektivi konkret elm sahələri üzrə elmi biliklərə malik mütəxəssis və alimlərdən formalaşır. Lakin maraq doğuran digər bir məsələ isə elmi sahə üzrə ilkin təhsili olmayan yüzlərlə, minlərlə həvəskarın konkret qlobal layihələrdə iştirakı ilə xarakterizə olunan vətəndaş elmidir.

Vətəndaş elmi geniş məkan və zaman ölçüləri, böyük həcmli verilənlərin toplanması, kəmiyyət ölçmələri və müşahidələr, məlumatların toplanmasında açıq təbii şəraitdə çoxlu sayda könüllünün iștirakı, maliyyələşdirilmənin olmaması, verilənlərin onlayn toplanması, yaxșı işlənmiş tədqiqat mexanizmlərinin olması, dəstək üçün yardımçı materiallar və professional köməyin təqdim olunması və s.kimi xüsusiyyətləri ilə xarakterizə olunur.

Elmi fəaliyyətdə daha sürətlə inkişaf edən bu hərəkatbeynəlxalq səviyyədə böyük maraq yaratmaqla bərabər daha geniş səviyyədə dəstəklənir. Beləki, Yunesko, Avropa Komissiyas1 və onun Otraf mühit üzrə Avropa Agentliyi, həmçinin Birləşmiş Krallığın Đtraf mühitin Müşahidəsinin Çərçivə proqramı kimi milli səviyyəli siyasi orqanlar özlərinin hazırk1 fəaliyyəti və gələcək siyasi istiqamətləri üçün vətəndaş elminin vacibliyini tanımışlar[2]. Buna əsas verən çoxsaylı səbəbləri, məsələn, vətəndaş elminin elm, texnologiya, mühəndislik sahələrində tətbiqinin və təbliğinin vacibliyinə artan tələbatı, vətəndaş elmi vasitəsilə toplanmış informasiyadan siyasətin formalaşmasında və icra edilməsində istifadə olunmasını, vətəndaş elminin dəqiqliyi və keyfiyyətinin artmasını təsdiq edən araşdırmaları, onun iştirakçılarının və istehsal olunmuş verilənlərinin sayı baxımından əhatə dairəsini və miqyasınımisal göstərmək olar.

Vətəndaş elminə cəlb olunanların miqyasına və əhatə dairəsinə nəzər salsaq, görərik ki, onun cari formaları elmi- 
tədqiqatda ictimai iştirakın əvvəlki formalarını kölgədə qoymuş və iştirakçıların qabiliyyətlərində, biliklərində mühüm dəyişikliklər baş vermişdir. Bunuda vətəndaş elminin inkişafına təkan verən siyasi və texnoloji amillərlə izah etmək olar. Qeyd etmək lazımdır ki, XX-ci əsrin ikinci yarısı ərzində təhsilin sürətli inkişafi, xüsusilə inkişaf etmiş ölkələrdə asudə vaxtın və təhsil almış bacarıqlı təqaüdçülərin sayının artması ictimai iştirakın əhatə dairəsini genişləndirmişdir. Texniki baxımdanisəvebvəmobiltexnologiyalarınyaranması,inkişafıvəg enişimkanları mühüm əhəmiyyət kəsb edir. Xüsusən, ətrafmühitdənböyüksaydapaylanmışverilənləritoplayabilənucuz sensorlarıninkişafıvəyayılmasıiləyanaşı, son onillikdəWeb 2.0intətbiqləriilə formalaşan sosial ünsiyyət vasitələri mühüm rol oynamışdır.

Web 2.0 texnologiyasının sürətli inkişafi insanlara coğrafi yerləşmələrindən asılı olmayaraq sosial şəbəkələrə qoşulmaq imkanı yaratmışdır. Bu texnologiya əsasında yaradılmış sosial şəbəkə xidmətləri q1sa müddət ərzində rahat ünsiyyət və fayl mübadiləsi vasitəsindən unikal kontent generasiya edən və yayan sosial mediaya çevrilmişdir.Sosial medianın vətəndaş elmi ilə mühüm əlaqəsi vardır, çünki vətəndaş elmi layihələri getdikcə daha çox texnologiyalara əsaslanır, tələb olunan verilənlər onlayn portallar və mobil tətbiqlər vasitəsilə toplanır. Sosial element könüllülərin iştirakına motivasiya vermək üçün vacib sayıla bilər, ona görə də verilənləri geniş miqyasda sərbəst əldə edən vətəndaş alimlər üçün sosial media layihələrini müzakirə etmək, nəticələri paylaşmaq üçün forumlar təşkil etmək mühüm əhəmiyyət daşıyır. Sosial media artıq könüllüləri layihələrə cəlb etmək və alınmış nəticələr haqqinda informasiya əldə etmək üçün əks əlaqə ilə təmin etmək vasitəsinə çevrilmişdir.

Araşdırmalar göstərir ki,son illərdə vətəndaş elmi təşəbbüslərinin sayında sürətli artım vardır və əhatə dairəsinin miqyası, cəlb olunmuş könüllülərin sayı, mövzü müxtəlifliyi və s. ilə seçilirlər. $\mathrm{Bu}$ artım müasir texnologiyaların inkişaf səviyyəsi ilə sıx bağlıdır. Həmin asılılıqvətəndaş elminin həyata keçirilməsində müasir texniki və proqram vasitələrinin təyinatlı tətbiqinin aşağıda göstərilmiş nümunələrin iləizah oluna bilər:

- İştirakçıların layihələrlə və biri-biri ilə tanışlığında, müvafiq işçi komandanın formalaşdırılmasında və nəticələrin yayılmasında sosial şabəkəlorin (Facebook, Twitter,LinkedIn və s.) imkanlarından geniş istifadə olunur;

- Məlumatların toplanmasi, saxlanması və emalında aşağıdakı vasitələrdən istifadə olunur:

$\checkmark$ Mobil texnologiyalar və smartfonlardan istifadə olunması məlumatların toplandığı coğrafi məkanın GPS-lə dəqiq qeydiyyatı, toplanmış geoəlaqəli şəkillərin sonrakı emalı zamanı yoxlanılması və verifikasiyası məsələlərində mühüm rol oynayır.

$\checkmark$ Smartfon, iPhone vo s. daxilində yerləşdirilmiş xüsusi təyinatlı sensorlarfiziki proseslərin ölçülməsi və qeydiyyatını asanlaşdırır.

$\checkmark \quad$ Şəkillərin və səsin emalında OLAP, Data Mining və digər intellektual analiz texnologiyaları tətbiq olunur;
- Vizuallaşdırma və analizdə Google maps, Google charts, Fieldscopeistifadə olunur;

- Verilənlər bazalarının yaradılmasında və verilənlərin idarə olunması, axını və paylanmasındaproqram mühəndisliyinin son nailiyyətlərindən geniş istifadə olunur.

\section{VӘTӘNDAŞ ELMINDӘ İSTIFADӘ OLUNAN TEXNIKİ-TEXNOLOJI VASITTOLOR}

Vətəndaş elmi təşəbbüslərində təkrarçılığa yol verilməməsi və tədqiqatların səmərəliliyinin yüksəldilməsi məqsədi ilə təşkil olunmuşassosiyalar, fondlar, şəbəkələrvə digər uyğun təyinatlıvətəndaş elmi təşkilatları oxşar təcrübələrin və alınmış nəticələrin, o cümlədən yaradılmış proqram vasitələrinin bölüşdürülməsi və təkrar istifadə olunmasında, birgə fəaliyyətlərin təşkilində, yeni layihələrin formalaşdırılmasında mühüm rol oynayır. Bu konteksdə, aşağıda təqdim olunan misalları nəzərdən keçirək.

Mental Modeler fərdlər və cəmiyyətlərə öz biliklərini ssenarilərin təhlili üçün istifadə oluna biləcək standartlaşdırılmış formatda təqdim etməyə kömək edən proqram təminatıdır[3]. Bu proqram təminatı istifadəçilərə real zamanda sistem haqqında öz fərziyyələrini birgə təqdim etmək və yoxlamaq imkanı verən qrup qərar qəbul edilməsinə dəstək üçün yaradılmışdir. Olavə olaraq, o, həmçinin qərar qəbul etməni şərtləndirən fərdi və ya ümumi "mental modelləri" ölçmək üçün sosial elmi-tədqiqat aləti kimi də tətbiq olunur

Vətəndaş elmi layihələri üçün işlənmişonlayn proqram təminatları vətəndaş alimlərə real dünya problemlərini həll etməyə yardım edir.Belə ki, ətraf mühitin qorunması üzrə aparılmış araşdırmalar göstərir ki, uyğun təlimlər və son dövrlərdə quraşdırılmış onlayn proqram təminatı və veb-portal vasitəsi ilə vətəndaş alimlər elmi əsaslarla bu sahədə qərarların qəbulunu təkmilləşdirə, həmçinin ekoloji problemlərin həllinin maliyyələşdirilməsini təmin edə bilirlər[4]. Miçiqan Dövlət Universiteti (Michigan State University) bir qrup tədqiqatçısının araşdırmaları göstərir ki, bu vasitələrin hazırkı üstünlükləri təkcə vətəndaş elmində deyil, həm də biologiyanın qorunması sahəsində də inkişafa imkan verir. Tədqiqatçılar qrupu Mental Modeler və Universitetdə lider olan onlayn proqram təminatından istifadə edərək suyun çirklənməsini azaltmaq üçün ağıllı bir həll yolu tapmışlar. Araşdırmaların bir hissəsi kimi Virciniya cəmiyyəti qrupu, həmçinin Rutgers Universiteti (Rutgers University) və Kolorado Dövlət Universitetinin (Colorado State University) əməkdaşları birlikdə təkmilləşdirilmiş vətəndaş elmi veb-portalından istifadə etmişlər [5].

Mental ModelerUnited States Department of Agriculture and the National Science Foundation fondunun maliyyələşdirməsi ilə yaratmışdır.

The Collaborative Science layihəsi Kolorado Dövlət Universitetində təqribən 400 layihəyə və 3400 iştirakçıya yardım etmiş CitSci.org ilə birgə işləmək üçün yaradılmışdır. Layihədə açıq, şəffaf mühitdə iştirak edən hər kəs potensial tədqiqat və ya idarəetmə variantlarını müzakirə və bununla bərabər vətəndaş elminin tədqiqat planlarını inkişaf etdirə bilər.

CitSci.org vətəndaş elmi layihələrinin internetdə eyni məkanda birləşdirməyə imkan verən veb portaldır [6]. Təbii 
resursların ekologiyasının müxtəlif məsələlərinin həlli üçün yaradılmışdır. O, yeni layihələr yaratmaq, toplanmış verilənlərin təhlili, iștirakçıların rəylərinin toplanılması və $\mathrm{s}$. kimi məsələlərin həllində proqram vasitələri və resurslar təqdim etməklə yeni başlanmış tədqiqatlara dəstək verir. CitSci.org-a üzv olaraq, vətəndaş alimlər özlərinin elmi işlərini bölüşməklə yanaşı, mövcud olan layihələrə könüllü qoşulmaq imkanı əldə edirlər. CitSci.org tədqiqata kreativlik qatmaq imkanı yaradan xüsusiyyətlərinə görə digər oxşar portallardan fərqlənir. Portal yeni layihələrin yaradılması, idarə olunması, hər hansı bir layihəyə üzv olmaq, verilənlərin təhlil edilməsi kimi funksiyaları yerinə yetirir.

Citsci.org qarşısına aşağıdakı məqsədləri qoymuşdur:

- Vətəndaş elminin ehtiyaclarının bütöv spektrini dəstəklənməsi;

- Vətəndaş elmi verilənlərinin dəqiqliyinin artırılması;

- Verilənlərin standartlaşdırılması, qarşılıqlı təsiri, inteqrasiyası, əlyetərliyi və yayılmasının təkmilləşdirilməsi.

Layihələr üzrə çoxlu sayda müxtəlif ölçmələr aparılır. Maraqlısı odur ki, istifadəçi buraya ixtiyari ölçməni əlavə edə və ya özü onun vahidini təyin edə bilər. Bu mənada citsci.org vətəndaş alimlərə kreativlik üçün şərait yaradır. Ölçmələrə düzəliş etmək üç şərtlə mümkündür: 1) istifadəçinin özü tərəfindən yaradılıbsa; 2) mövcud verilənlərlə əlaqəli deyilsə və 3) hər hansı bir layihənin texniki pasportunda istifadə olunmursa.CitSci.org layihələrin daha keyfiyyətli olması üçün Citizen Science Central[7] vəDataONE-la [8] əməkdaşlıq edir.

Hazırda ona qoşulan könüllü koordinatorlar yaratdıqları 406 layihə üzrə lokal, regional və/və ya qlobal problemlərin həlli üçün ümumilikdə 686728 ölçmə (analiz üçün verilənlər) aparıblar[6].

Dünyada vətəndaş elmi layihələrinin sayının olduqca böyük olduğunu, təkcə bu portalın timsalında göstərilmiş rəqəmlərlə müqayisədə təsəvvür etmək olar (şəkil 1).

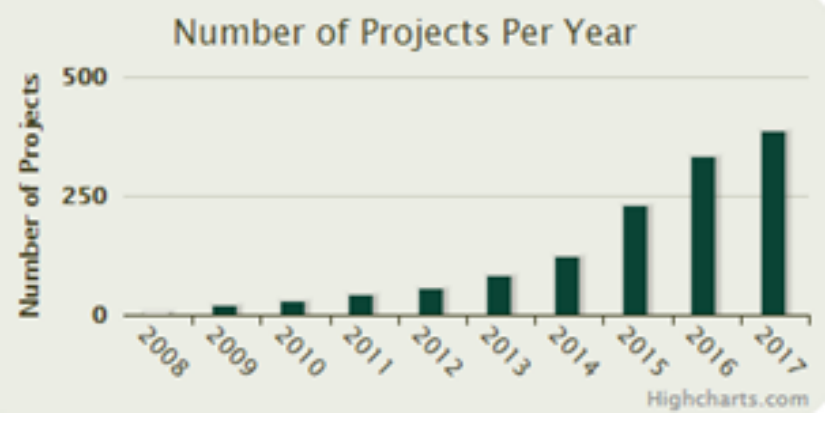

Şəkil 1.CitSci.org- da layihələrin artım dinamikası

Citsci.org təkcə tədqiqat araşdırmaları üçün geniş sahə deyil, həmçinin digər tədqiqatçılar burada verilənlər və modellər axtara bilərlər. Tədqiqatçılar vətəndaş elminin reallaşması prosesini və meydana gələn verilənlərin keyfiyyətini daha yaxşı başa düşmək üçün buradakı işləri təhlil edir və araşdırırlar. Vətəndaş elmi haqqunda daha çox öyrənməklə bərabər onlar həmçinin paylaşılmış layihələrdən alınmış nəticələrdən istifadə edirlər. Nəticədə müxtəlif mənbələr tərəfindən aparılmış oxşar araşdırmaların inteqrasiyasından alınmış meta-təhlil verilənləri daha geniş olan bir məsələnin həlli üçün istifadə edilir.

Onun yeni layihələrin yaradılması, iştirakçıların idarə olunması, verilənlərin emalı, verilənlərin təhlili və nəticələrin qiymətləndirilməsi üçün işlənmiş proqram vasitələri hazır xidmətlər kimi istifadəçilər üçün açıqdır.

Panoptes (Panoptic Astronomical Networked Observatories for a Public Transiting Exoplanets Survey)astronomik müşahidələr üçün istifadə edilə bilən aşağ qiymətli robotlaşdırılmış teleskoplar qurmaq məqsədi daşıyan vətəndaş elmi layihəsidir[9]. Layihə dünyada belə layihələrdən ən uğurlusu olan Zooniverse-i dəstəkləyir və son istifadəçilərə - tipik olaraq böyük verilənlər toplusu ilə işləyən alimlər və tədqiqatçılara -brauzerlə sadə alətlərdən istifadə etməklə işçi təsnifat proseslərini hazırlamaq imkanı verir. Panoptes ixtiyari istifadəçiyə proqramlaşdırma aparmadan birbaşa brauzerdə layihə qurmaq imkanı verir.

Panoptes-in təqdim etdiyi proqram vasitələrindən PIAA (Panoptes Image Analysis Algorithm) təsvirlərin analizi üçün hazırlanmış platformadır. Onun ilkin, aralıq və son emal nəticəsində alınmış verilənlərin saxlanılması və təhlili imkanları vardır.

PANOPTES Environmental Analysis System (PEAS) ətraf mühitin analizi sistemiisə küləyin sürətini, havanın temperatunu, rütubəti və s. parametrləri ölçən sensorlardan alınmış verilənlərin analizini həyata keçirən proqram vasitəsinə malikdir.

DataONE (Data Observation Network for Earth) Yer haqqinda verilənlərin müşahidəsi üçün mövcud arxiv təşəbbüsləri, kitabxanalar, ətraf mühitin müşahidəsi sistemləri və tədqiqat şəbəkələri, verilənlərin və informasiyanın idarəedilməsi, elmi mərkəzlər və peşəkar cəmiyyətlər də daxil olmaqla müxtəlif sahələrdə on ildən çox təcrübəsi olan iştirakçı təşkilatlar arasında təcrübə və əməkdaşlıq əlaqələri qurmaq məqsədi ilə yaradılmış şəbəkədir[8]. Onun təqdim etdiyi proqram vasitələri və tərkibində fəaliyyət göstərən İşçi qruplar kiberinfrastrukturun müəyyən edilməsi və ictimaiyyətin cəlb olunması ilə tədqiqatların aparılmasında, eyni zamanda konkret tədqiqat, təhsil və kiberinfrastruktur problemləri üçün fəaliyyəti təşkil etmək və həllər təklif etməkdə mühüm rol oynayırlar.

Beləliklə, yuxarıda aparılmış araşdırmaların nəticəsi kimi açı proqram vasitələrinin vətəndaş elminin inkişafi üçün geniş imkanlar açdığı təsdiq olunur.

\section{NӘTİCə}

Araşdırmalar göstərir ki, son illər ərzində e-elmin inkişafının yeni istiqaməti olan vətəndaş elmininformalaşması və inkişafinda proqram mühəndisliyinin son nailiyyətləri mühüm rol oynayır. Bu sahədə mövcud olan açıq kodlu proqram vasitələrindən istifadə etməklə əlavə vaxt və maliyyə sərf etmədən vətəndaş elminin daha səmərəli inkişafina nail olmaq olar.

\section{ӘDӘВIYYAT}

[1] T.X.Fətəliyev, Vətəndaş elmi e-elmin inkişafının yeni istiqaməti kimi, İnformasiya cəmiyyəti problemləri, 2014, №1,s. 57-64 
[2] M.Haklay,Citizen Science and Policy: A European Perspective. www.wilsoncenter.org/publication/citizen-science-and-policy-europeanperspective

[3] Mental Modeler, www.mentalmodeler.org

[4] https://phys.org/news/2016-10-online-software-citizen-scientists-realworld.html

[5] www.collaborativescience.org

[6] http://citsci.org/cwis438/websites/citsci/home.php?WebSiteID=7

[7] www.birds.cornell.edu/citscitoolkit/

[8] www.projectpanoptes.org

[9] DataONE, www.dataone.org

$B u$ iş Azarbaycan Respublikasının Prezidenti yanında Elmin Inkişafi Fondunun maliyya yardımı ila yerina yetirilmişdir - Qrant № EIF-2014-9(24)-KETPL-14/02/1 